\title{
Aquatic Coleoptera and Heteroptera inhabiting waterbodies from Berisso, Buenos Aires province, Argentina
}

\author{
Liliana A. Fernández \& Mónica L. López Ruf \\ División Entomología del Museo de La Plata. Paseo del Bosque 1900 FWA La Plata, Buenos Aires, Argentina; \\ liliafer@museo.fcnym.unlp.edu.ar
}

Received 25-II-2005. Corrected 15-VII-2005. Accepted 31-VIII-2005.

\begin{abstract}
Coleoptera and Heteroptera associated with aquatic environments were studied at Berisso, near Río de La Plata estuary (Buenos Aires Province, Argentina). Four waterbodies were characterized and compared: artificial pond, shallow pool, stream and artificial channel. Sampling was done twice a month, with a round sieve, for 12 months (April 1999 to April 2000). Sampling was quantified using a discrete unit of time (one hour/worker). Where floating vegetation was present, four $25 \mathrm{~cm}$ diameter samples were extracted and placed in a Berlese-Tullgren funnel for 48 hours. Temperature, $\mathrm{pH}$ and conductivity were measured. Specimens were preserved in $70^{\circ}$ ethanol. Similarities in taxonomic composition among sampling stations were quantified using Jaccard's index based on a presence/absence matrix for the insect fauna of each sampling station. A total of 68 species belonging to 8 families of Coleoptera and 11 families of Heteroptera were collected. The highest number of species (41) was recorded in the shallow pool (stream 34 species; artificial pond 29; artificial channel 25). The highest specific diversity values were observed during spring in all sampling stations. The highest frequency of Coleoptera was shown by Helochares talarum Fernández and Suphisellus nigrinus (Aubé) (?). In the Heteroptera it was shown by Lipostemmata humeralis Berg, Lipogomphus lacuniferus Berg and Rheumatobates bonariensis (Berg). The most abundant species were not necessarily the most frequent ones. Coleoptera is the most important group in species richness. Each environment had a taxocoenosis of Coleoptera and Heteroptera with inherent characteristics. Rev. Biol. Trop. 54(1): 139-148. Epub 2006 Mar 31.
\end{abstract}

Key words: Aquatic insects, Coleoptera, Heteroptera, species richness, biodiversity, Argentina.

Conservation of biological biodiversity is, at present, a worldwide concern. One of the first steps to be considered by biologists in this regard is to carry out an inventory of the species inhabiting each ecosystem, and to know their main attributes. In this way we will be able to evaluate in the future the impact resulting from the modifications performed in the environment by human action.

Insects represent the most diversified biological group within the arthropods, having occupied very heterogeneous functional and environmental niches. As it is known, they are the most numerous but less well-known animal "specific components". In addition, insects are essential elements in most trophic and energetic chains. Although this group shows the highest diversity among the invertebrates, relatively little attention has been paid to its inventory and monitoring (Sandways 1994). The monitoring of insects can provide a rapid signal of environmental changes useful for the management of natural areas. Among aquatic insects, Coleoptera and Heteroptera constitute a useful tool for the evaluation of biodiversity due great number of species they include. Furthermore, they colonize different types of environments, and their presence in the limnotopes occurs year-round. Additionally, they are important indicators of spatial and temporal changes in environments. This is the reason why some authors have used them as indicators 
of the ecological quality of the aquatic ecosystems (Eyre and Foster 1989, Ribera and Foster 1993, González and Valladares 1996, Millán, et al. 2001, Sanchez - Fernández et al. 2004).

In the area of Berisso (province of Buenos Aires, Argentina), studies about population ecology and systematics of aquatic Coleoptera and Heteroptera were carried out in recent decades (Fernández 1983, 1990, Estévez et al. 1987, López Ruf et al. 2000, López Ruf and Pérez Godwyn 2001, Domizi et al. 1978, Schnack et al. 1980, 1986, 1989). Nevertheless, there are no studies that consider the composition and dynamics of the aquatic Coleoptera and Heteroptera communities within this area, located in an urban zone, influenced by human activity.

The aim of this paper is to study aquatic and semiaquatic Coleoptera and Heteroptera inhabiting four limnotopes from the Partido de Berisso (Buenos Aires Province), as well as to compare their main attributes: frequency, abundance, species richness and diversity.

Study area: The study area was located in Los Talas (Berisso, Buenos Aires Province). Four sampling stations were selected.

Station A (artificial pond): A permanent body water located at $30 \mathrm{~m}$ from the Ruta Provincial $\mathrm{N}^{\circ} 15$, in the border of the relictual area of the Rio de La Plata gallery forest (3453'39' S; 5749'00”' W). The limnotope is an artificial depression generated to extract rock shells. It has regular boundaries with a maximum depth of $2.40 \mathrm{~m}$ and is fed by rainfalls, by the overflow of an adjacent channel, and by ground water. Samplings were carried out at the banks where the depth was $50 \mathrm{~cm}$. It was usually covered by Spirodela intermedia W. Koch., Lemna sp., Wolfiella oblonga (Phil.) Hegelm. and Azolla filliculoides Lam. surrounded by Scirpus giganteus Kunth and shaded by Erythrina crista-galli L. and Arundo donax L.

Station B (shallow pool): semipermanent shallow pool, located within the grassland, fed by a narrow stream which empties into the Río de la Plata, with a great quantity of sedimented organic matter, partially shaded by trees (3453'57' S; 57²8'24” W). It was dry only in January. The following plants were registered: Polygonum punctatum Elliot, Eleocharis bonaeriensis Ness., Hydrocotyle ranunculoides L., Ludwigia peploides (Kunth) P. H. Raven, Liliaenopsis minor (Hill.) Pérez Moreau, Miriophyllum sp., Spirodela intermedia W. Koch, Azolla sp. Wollfiella sp. and Lemna sp.

Station C (stream): located in El Pescado stream, at the crossing of Provincial Road $\mathrm{N}^{\circ} 15$ (345' $\left.42^{\prime \prime} \mathrm{S} ; 7^{\circ} 45^{\prime} 33^{\prime \prime} \mathrm{W}\right)$. El Pescado stream has its source near La Plata city and after $36 \mathrm{~km}$ discharges into the estuary of the Rio de La Plata. Samplings were carried out in an area with steep banks, without floating vegetation, with the following aquatic plantas in a small site: Echinodorus grandiflorus (Cham. et Schltdl) Micheli, Schoenoplectus californicus (Kunth), Sagittaria montevidensis Cham. et Schtdl and Senecio bonaeriensis Hook et Arn.

Station D (artificial channel): located in the marginal forest of the Rio de La Plata estuary shore, in a section of an artificial channel connecting with the Rio de La Plata (345' $52^{\prime}$ " S; 57 $43^{\circ} 11^{\prime}$ W). The following plants were registered: Egeria densa Planch. and Potamogeton striatus Ruiz et Pavon.

\section{MATERIAL AND METHODS}

During a period of 12 months, from April 1999 to April 2000, samplings were carried out twice a month. Samplings were made with a round sieve, and samples were quantified using a definite unit of time (one hour/worker), when the floating vegetation was present; also four $25 \mathrm{~cm}$ diameter samples were extracted and placed in Berlese-Tullgren funnel for 48 hours. Specimens were preserved in $70^{\circ}$ ethanol, and posteriorly identified. For each sampling station presence frequency ( $\mathrm{F} \%)$ and dominance or relative abundance (D \%) was calculated for each species, as well as its richness (S), and diversity (H'). A Shannon and Weaver index was used to obtain the specific diversity values (Shanonn and Weaver 1963). Taking into account the frequency and relative abundance 
values, the different populations which comprise the studied communities according to categories proposed by Velasco et al. (1993) have been classified.

Similarities in taxonomic composition among sampling stations were quantified using Jaccard's index (Sneath and Sokal 1973) based on a presence/absence matrix for the insect fauna of each sampling station. Three abiotic parameters were mesured to characterize the habitat: temperature, $\mathrm{pH}$ and conductivity (Table 1).

\section{RESULTS}

Species richness and diversity: A total of approximately 19400 specimens belonging to eigth families of Coleoptera and 11 families of Heteroptera were collected. The highest number of species (41) was registered in the shallow pool, whereas in the stream 34 species were found, 29 in the artificial pond and 25 in the artificial channel. Richness and specific diversity values corresponding to the four stations can be seen in Table 2. With respect to specific diversity, the highest values were observed during spring in all the sampling stations.

Coleoptera: A total of approximately 5400 individuals belonging to 27 genera and 48 species were collected (Appendix). Hydrophilidae was the best represented family accounting for 31.57 to $52.17 \%$ of the species recorded; Dytiscidae and Noteridae accounted for $21.73 \%-36.84 \%$ and $8.69-31.57 \%$ respectively, whereas the remaining families (Hydrochidae, Dryopidae, Limnichidae, Heteroceridae and Scirtidae) represented $3.00-6.25 \%$ of the total number of species (Fig. 1). The richest fauna of Coleoptera occurred in the still waters at Station B (33).

Heteroptera: A total of approximately 14000 individuals belonging to 15 genera and 20 species were collected (Appendix). Percentage of species per family in each sampling station can be seen in Fig. 2. Corixidae contributed

TABLE 1

\begin{tabular}{lcc} 
Sampling station & \multicolumn{2}{c}{ Temperature $\left({ }^{\circ} \mathrm{C}\right)$} \\
Station A & $19.00 \pm 4.86$ & $12-26$ \\
Station B & $21.53 \pm 3.44$ & $8-26$ \\
Station C & $17.76 \pm 6.22$ & $9-28$ \\
Station D & $17.44 \pm 5.48$ & $9-26$
\end{tabular}

\begin{tabular}{cccc}
\multicolumn{2}{c}{$\mathrm{Ph}$} & \multicolumn{2}{c}{ Conductividad $(\mathrm{mS} / \mathrm{S})$} \\
$7.32 \pm 0.32$ & $7.16-7.78$ & $0.94 \pm 0.34$ & $0.63-1.31$ \\
$6.84 \pm 0.19$ & $6.57-7.38$ & $0.74 \pm 0.05$ & $0.68-0.85$ \\
$7.28 \pm 0.45$ & $6.67-7.78$ & $0.95 \pm 0.20$ & $0.71-1.31$ \\
$6.91 \pm 0.26$ & $6.40-7.25$ & $1.24 \pm 0.17$ & $1.00-1.53$
\end{tabular}

TABLE 2

\begin{tabular}{|c|c|c|c|c|}
\hline & Station A & Station B & Station $\mathrm{C}$ & Station D \\
\hline Average species richness & $9.66 \pm 3.84$ & $12.04 \pm 4.50$ & $4.60 \pm 2.92$ & $4.85 \pm 2.90$ \\
\hline Average species diversity & $1.17 \pm 0.34$ & $1.61 \pm 0.48$ & $0.73 \pm 0.23$ & $1.29 \pm 0.44$ \\
\hline Maximum species richness & 17 & 19 & 12 & 12 \\
\hline Maximum species diversity & 2.18 & 2.29 & 1.09 & 2.34 \\
\hline Total of species & 29 & 41 & 34 & 25 \\
\hline Total of specimens & 9008 & 6801 & 2922 & 355 \\
\hline
\end{tabular}




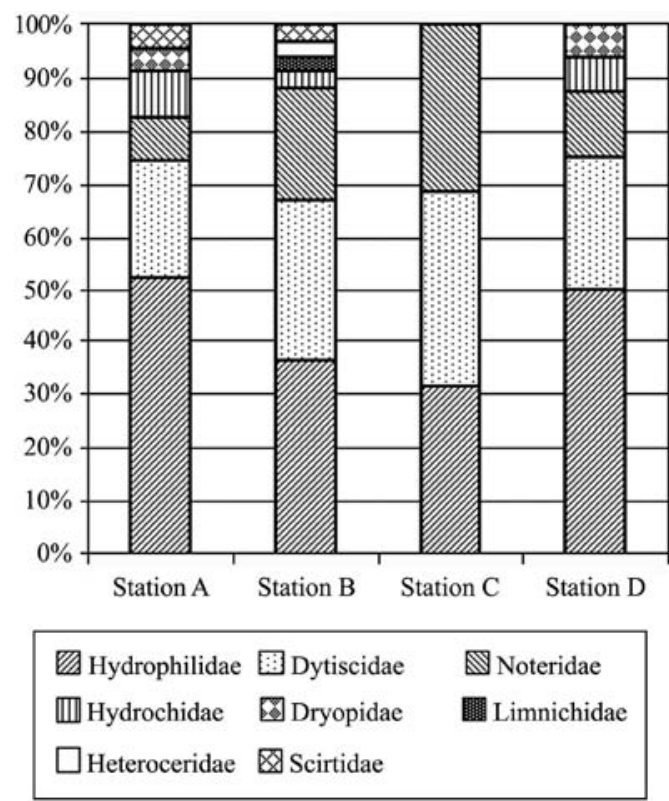

Fig. 1. Coleoptera: percentage of species per family in each sampling station.

the highest number of species, accounting for 22.11 to $28.57 \%$ of the species recorded; Belostomatidae and Pleidae both accounted for 7.14 to $28.57 \%$, whereas the remaining families (Hebridae, Notonectidae, Hydrometridae, Nepidae, Gerridae, Mesoveliidae, Veliidae and Rhyparochromidae) represented 7.14$14.28 \%$ of the total number of species (Fig. 2). The richest fauna of Heteroptera occurred in Stations C and B.

The relation between the number of species of Coleoptera and Heteroptera, considering each sampling station separately, was of approximately $4: 1$ in stations $A$ and $B ; 2: 1$ in station D and 1:1 in station C.

Frequency and abundance: The highest frequency of Coleoptera was shown by Helochares talarum (Fernández) and Suphisellus nigrinus (Aubé) (?). While in the Heteroptera it was shown by Lipostemmata humeralis (Berg), Lipogomphus lacuniferus (Berg) and Rheumatobates bonariensis. The most abundant species registered were not necessarily the most frequent ones (Figs. 3-6).
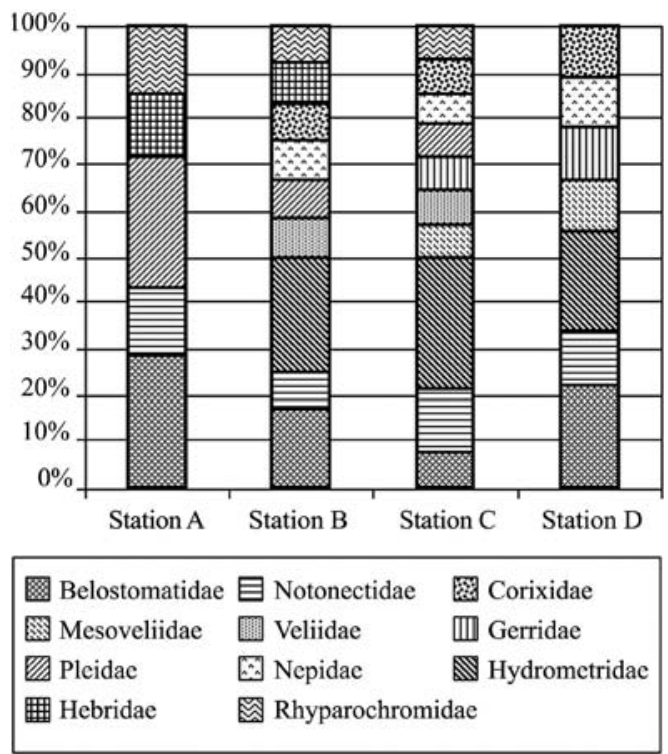

Fig. 2. Heteroptera: percentage of species per family in each sampling station.

The species contributing with the highest number of specimens, over 800 individuals, belong to the families: Rhyparochromidae, Hebridae and Gerridae. Rhyparochromidae, with only one species, contributed approximately $50 \%$ of the total Heteroptera. Among Coleoptera, the most abundant species distributed in all the environments were: $S$. nigrinus ?, E. vulgaris, P. rufocinctus, T. setiger and Liodessus sp. 1. Helochares talarum, registered in two of the environments and S. nigrinus? contributed the highest number of specimens.

Considering the frequency and relative abundance values (Figs. 3-6), a classification of the species forming the taxocoenosis of Coleoptera and Heteroptera of each sampling station, according to the categories proposed by Velasco et al. (1993) was carried out (Table $3)$. It can be noticed that the taxocoenosis are composed of a low number of fundamental species and of a great number of sporadic, accesory species.

Taxonomic similarity: The four environments were compared using association 
TABLE 3

Classification of species in terms of frequency and relative abundance categories. $F=$ frecuency, $D=$ relative abundance

\begin{tabular}{|c|c|c|c|c|c|}
\hline $\begin{array}{l}\text { Sampling } \\
\text { station }\end{array}$ & $\begin{array}{c}\text { Fundamental } \\
\mathrm{F}>50 \%, \mathrm{D}>10 \%\end{array}$ & $\begin{array}{c}\text { Constant } \\
\mathrm{F}>50 \%, \mathrm{D}<10 \%\end{array}$ & $\begin{array}{c}\text { Accompanying } \\
20 \%>\mathrm{F}<50 \%, \mathrm{D}<10 \%\end{array}$ & $\begin{array}{c}\text { Accesory } \\
6 \%>\mathrm{F}<20 \%, \mathrm{D}<10 \%\end{array}$ & $\begin{array}{c}\text { Sporadic } \\
\mathrm{F}<6 \%, \mathrm{D}<10 \%\end{array}$ \\
\hline Station A & $\begin{array}{l}\text { H. talarum } \\
\text { L. lacuniferus }\end{array}$ & $\begin{array}{l}\text { E. scutellaris } \\
\text { E. vulgaris } \\
\text { Paracymus sp. } \\
\text { T. ignoratus } \\
\text { Scirtidae Gen A sp. } 1 \\
\text { B. oxyurum } \\
\text { L. humeralis }\end{array}$ & $\begin{array}{l}\text { E. variegatus } \\
\text { T. setiger } \\
\text { Liodessus sp. } 1 \\
\text { N. maculosa }\end{array}$ & $\begin{array}{l}\text { T. ovalis } \\
\text { A. silvestrii } \\
\text { B. acuminatus * } \\
\text { D. concolor } \\
\text { Suphisellus sp. } 2 \\
\text { S. nigrinus? } \\
\text { H. richteri } * \\
\text { H. orchymonti }\end{array}$ & $\begin{array}{l}\text { B. adustus } \\
\text { D. paranensis } \\
\text { D. argentinensis } \\
\text { H. pallipes * } \\
\text { Desmopachria sp. } \\
\text { Dryops sp. * } \\
\text { B. elegans } \\
\text { N. absona * }\end{array}$ \\
\hline Station B & $\begin{array}{l}\text { S. nigrinus ? } \\
\text { L. humeralis } \\
\text { L. lacuniferus }\end{array}$ & $\begin{array}{l}\text { E. variegatus } \\
\text { E. vulgaris } \\
\text { Paracymus } \text { sp. } \\
\text { D. concolor } \\
\text { Liodessus } \text { sp. } 1 \\
\text { Suphisellus } \text { sp. } 2 \\
\text { Scirtidae sp. } 1 \\
\text { B. oxyurum } \\
\text { N. maculosa }\end{array}$ & $\begin{array}{l}\text { D. paranensis } \\
\text { T. setiger } \\
\text { Laccophilus } \mathrm{sp.} 1 \text { * } \\
\text { Laccophilus } \mathrm{sp.} 2 \\
\text { H. sharpi } \\
\text { S. obesus } * \\
\text { H. orchymonti } \\
\text { C. bonaerensis * } \\
\text { S. platensis } \\
\text { N. sellata }\end{array}$ & $\begin{array}{l}\text { H. talarum } \\
\text { E. scutellaris } \\
\text { T. ignoratus } \\
\text { A. silvestrii } \\
\text { H. turbinatus * } \\
\text { L. lugubris * } \\
\text { P. globosus * } \\
\text { R. signatus } \\
\text { P. punctipennis * } \\
\text { S. chrostowskii } \\
\text { S. schadei } \\
\text { M. mimula }\end{array}$ & $\begin{array}{l}\text { D. argentinensis } \\
\text { E. gentilis * } \\
\text { T. lateralis * } \\
\text { T. scutellaris * } \\
\text { R. orbignyi } * \\
\text { Mesonoterus sp. * } \\
\text { Suphis sp. } 2 \\
\text { H. similis * } \\
\text { Eulimnichus sp.* } \\
\text { B. elegans } \\
\text { H. argentina }\end{array}$ \\
\hline Station C & $\begin{array}{l}\text { H. platensis } * \\
\text { R. bonariensis }\end{array}$ & & $\begin{array}{l}\text { Paracymus sp. } \\
\text { Liodessus sp. } 1 \\
\text { Sigara } \text { sp. } \\
\text { Mesovelia bila }\end{array}$ & $\begin{array}{l}\text { E. vulgaris } \\
\text { D. concolor } \\
\text { Laccophilus sp. } 2 \\
\text { Liodessus sp. } 2 \\
\text { Suphis sp. } \\
\text { Suphisellus sp. } \\
\text { S. nigrinus? } \\
\text { B. fuscipennis* } \\
\text { S. platensis } \\
\text { R. segrega } \\
\text { L. humeralis }\end{array}$ & $\begin{array}{l}\text { E. tremolerasi } * \\
\text { E. variegatus } \\
\text { T. ovalis } \\
\text { T. setiger } \\
\text { Desmopachria } \mathrm{sp} \text {. } \\
\text { L. marginatus * } \\
\text { R. signatus } \\
\text { H. debilis * } \\
\text { H. laevigatus } \\
\text { S. bruchi } * \\
\text { B. elegans } \\
\text { N. sellata } \\
\text { S. chrostowskii } \\
\text { S. schadei } \\
\text { M. mimula * } \\
\text { H. argentina } \\
\text { N. maculosa }\end{array}$ \\
\hline Station D & $\begin{array}{l}\text { B. adustus } \\
\text { B. oxyurum }\end{array}$ & & $\begin{array}{l}\text { T. setiger } \\
\text { S. nigrinus ? } \\
\text { Sigara } \mathrm{sp} . \\
\text { T. fuscata } * \\
\text { R. bonariensis } \\
\text { M. bila } \\
\text { R. segrega }\end{array}$ & $\begin{array}{l}\text { D. argentinensis } \\
\text { D. paranensis } \\
\text { E. variegatus } \\
\text { E. vulgaris } \\
\text { Paracymus } \mathrm{sp} \text {. } \\
\text { Liodessus } \mathrm{sp} .1 \\
\text { R. signatus } \\
\text { H. orchymonti } \\
\text { N. sellata }\end{array}$ & $\begin{array}{l}\text { T. burmeisteri }{ }^{*} \\
\text { D. concolor } \\
\text { Liodessus } \mathrm{sp} .2 \\
\text { H. sharpi } \\
\text { Onopelmus sp. * } \\
\text { B. elegans } \\
\text { H. argentina }\end{array}$ \\
\hline
\end{tabular}

* Species found in only one environment. 
L. lacuniferus

$L$ humeralis

N. maculosa

N. absona

$B$ oxvurum

B. elegans

Scirtidae sp. 1 Dryops sp H. orchymont 1

Suphisellus $\mathrm{sp} .2$

$S$. nigrinus

Liodessus $\mathrm{sp}$.

D

D. concolor

acuminatus

silvestrii

T. setiger

T. ovalis

T. ignoratus

$P$. rufocinctus

H. talarum

$H$. pallipes $\square$

E. vulgaris

E. variegatus

E. scutellaris

D. paranensis

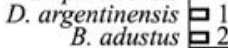

3
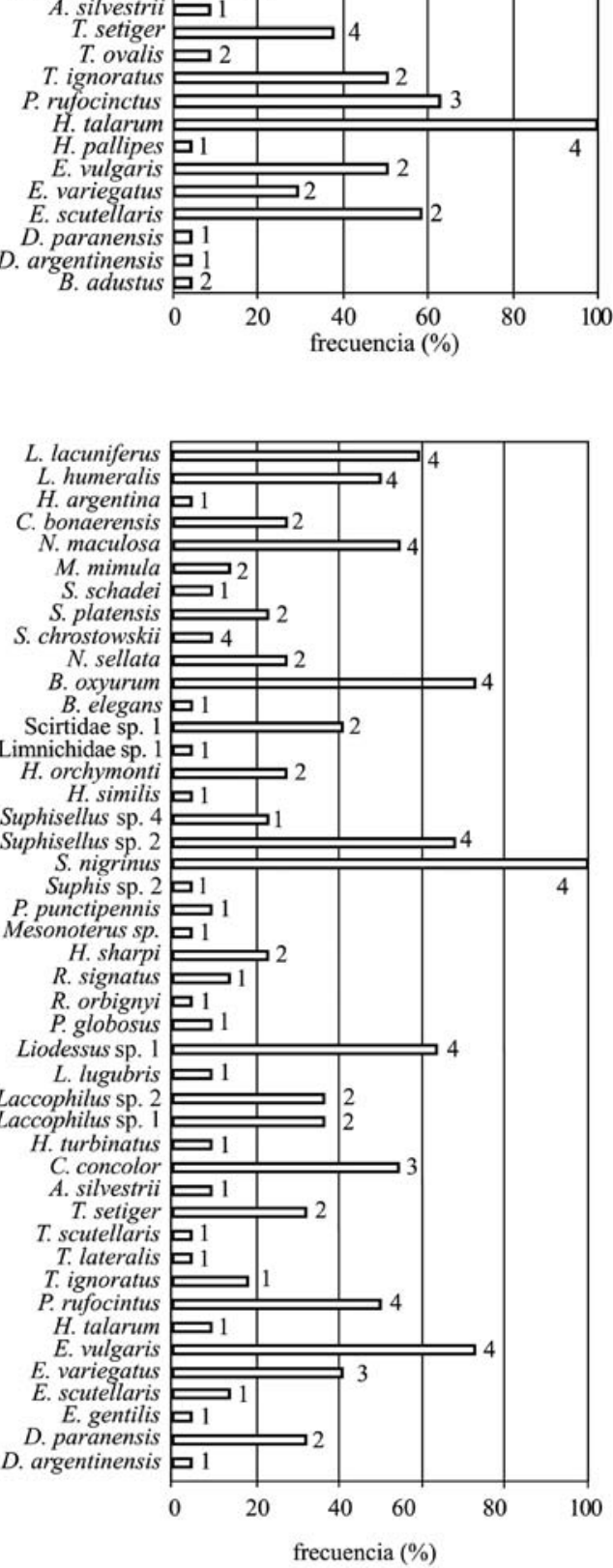
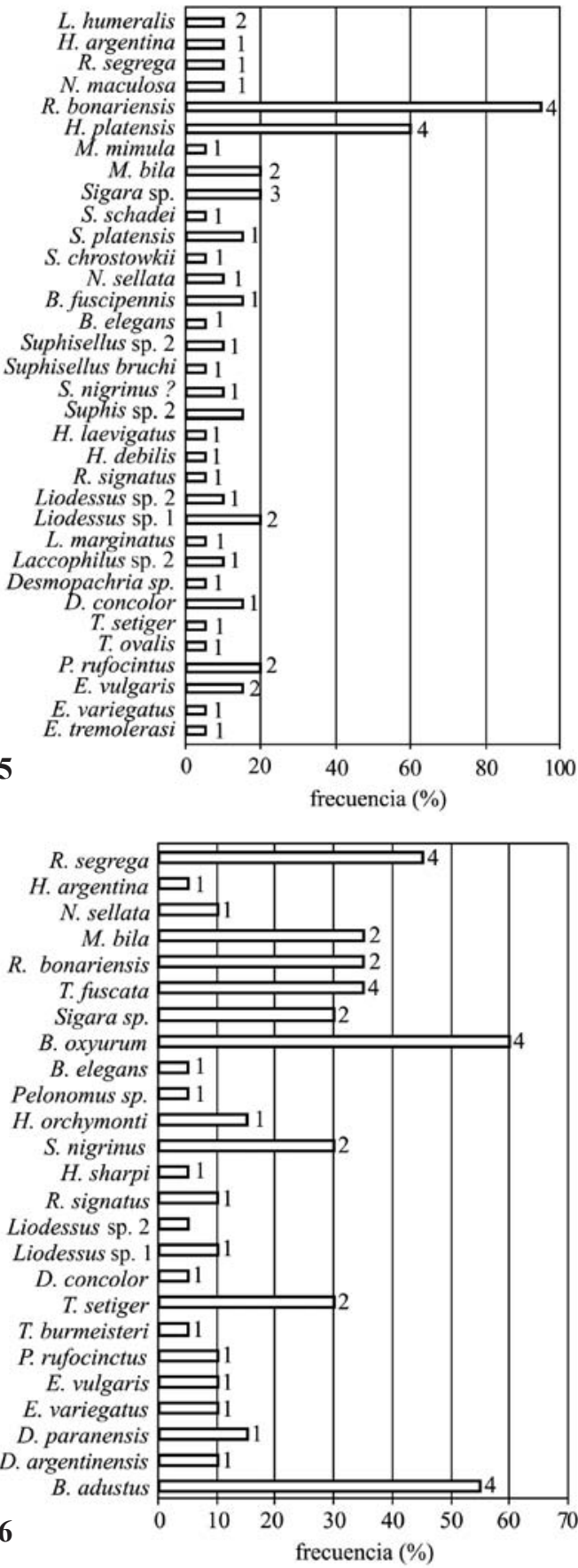

Figs. 3-6. Species frequency and abundance per sampling station. Horizontal bar: frequency; digit: maximum number of individuals registered in one or more samples (Scale: $1=$ $1-5 ; 2=6-25 ; 3=26-50 ; 4=51$ or more individuals). Fig. 3, artificial pond (station A). Fig. 4, shallow pool (station B). Fig. 5, stream (station C). Fig. 6, artificial channel (station D). 
coefficient (taxonomic similarity), resulting in a phenogram where two nuclei of low similitude are observed, one of them composed of lentic environments and the other by lotic environments (Fig. 7). Table 3 shows those species registered in only one environment.

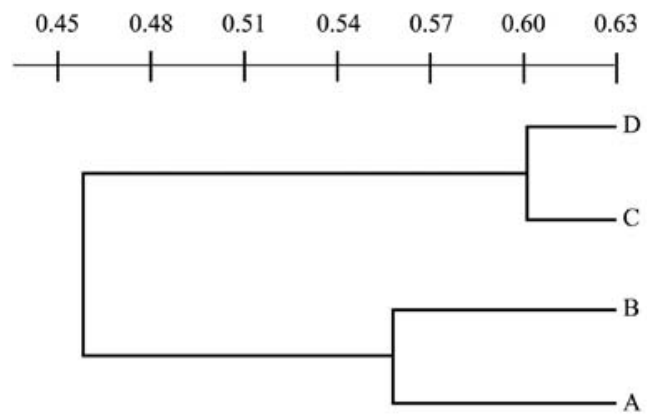

Fig. 7. Cluster analysis of sampling stations according to: Taxonomic similarity (Jaccard coefficient).

\section{DISCUSSION}

According to Millán et al. (2001) the general reduction in the number of species is accompanied by a diminishing in the proportion of richness of Coleoptera/Heteroptera. The highest abundance of Coleoptera in stations $\mathrm{A}$ and $\mathrm{B}$ is possibly due to the higher structural complexity of the environment, which allows species to insert in multiple trophic networks. On the other hand, stations $\mathrm{C}$ and $\mathrm{D}$ where the number of Coleoptera decreases with respect to Heteroptera, have less structural complexity and have received more human influence. Possibly due to this fact the presence of abundant "sporadic" and "accesory" species (characterized by their presence in a limited period of time and by a low population density) and the absence of "constant" species is observed. In El Pescado stream (station C) the lowest diversity values were observed, the number of specimens was increased by two "fundamental" species of the Gerridae family, which live on the surface of the water with no plants. As the area of this stream is subjet to agricultural and cattle-rearing activities and it has been channeled in several sectors, the overall quality of the ecosystem becomes drastically reduced as recovery of the biological water quality is not allowed.

In station A, among Coleoptera, H. talarum and Scirtidae larvae were more frequent and with a higher abundance value (fig. 3). This could be possibly due to the type of environment, presenting a lot of organic decomposing matter, from the abundant layer of floating plants. Hydrophilidae adults and Scirtidae larvae are collectors gatherers (Merrit and Cummins 1996), therefore bearing an important role in the recycling of organic matter from plants and animals. On the other hand, Hemiptera Lipogomphus lacuniferus and Lipostemmata humeralis constitute a group of "fundamental" or "constant" species in environments with an abundant coating of floating plants.

The presence of different micro environments generated by macrophytes could be more significant than the extension or repetition of such micro environments, macrophytes seem to have more importance at a qualitative level than at a quantitative one (Millán et al. 1996). This is in agreement with the observations performed at the grassland pool, where the highest specific richness and the highest average specific diversity were registered. This environment presents floating aquatic plants, rooted and marshy ones. An increment of specific diversity is expected due to the increase in the complexity of the habitat.

The environments studied are located in an urban zone, influenced by human activity, and in comparison with the data obtained in the area of Punta Lara (von Ellenrieder and Fernández 2000; von Ellenrieder and Pérez Goodwyn 2000), lower values of diversity, richness and total number of species have been observed in them. In agreement with La Salle and Gauld (1991) we consider that man is the main factor responsible for the biodiversity crisis, since its activities cause extinctions of species linked to the fragmentation or destruction of the environments due to overexploitation, introduction of exotic species, climatic establishment of populations, changes by anthropogenic effects, among other causes. 
Considering the Heteroptera, the following species have not been recorded in Los Talas: Pelocoris binotulatus nigriculus Berg, Belostoma cummingsi De Carlo and B. dentatum (Mayr), they were found in environments of the gallery forest of Punta Lara. No specimens of Belostoma micantulum (Stål), Sigara desenconscripta (Breddin), Lethocerus annulipes (Herrich-Schaeffer), Ranatra sjostedti Montandon and Nerthra ranina (HerrichSchaeffer) were collected either, although they could be expected in the area as they were found in low densities in Punta Lara. With respect to Coleoptera both areas share 35 species, 39 species found in Punta Lara were not found in Los Talas, although 13 species were collected only in the environments here studied.

With respect to the geographic distribution of the species registered, Buenos Aires Province is the southern limit for most of them, which are distributed in the Chaqueño and Amazonic domains of the Neotropical Region (Cabrera and Willink 1980); the Paraná River (Parano-Platense basin) is probably the corridor used by these species to reach this area (Ringuelet 1955). There are no aquatic and semiaquatic Heteroptera and Coleoptera species distributed exclusively in the study area. Only nine species which distribute as far as the Patagonic region were recorded: Tropisternus lateralis, T. setiger, Lancetes marginatus, Rhantus orbignyi Balke, R. signatus, Belostoma elegans, Buenoa fuscipennis, Sigara platensis and Hydrometra argentina.

\section{ACKNOWLEDGMENTS}

The authors acknowledge A. O. Bachmann, Silvia Mazzucconi and Edgardo Trémouilles for the determination of part of the entomological material, and Natalia Pedrol for helping with the separation of the samples. This study was supported by the Consejo Nacional de Investigaciones Científicas y Técnicas (CONICET - PIP $\mathrm{n}^{\circ}$ 700/98). This paper is a scientific contribution $n^{\circ} 786$ of the Instituto de Limnología "Dr. Raúl A. Ringuelet".

\section{REFERENCES}

Cabrera, A.L. \& A. Willink. 1980. Biogeografía de América Latina. Secretaría General de la O.E.A., Serie de Biología, Washington D.C., 13: vi + 122 p.

Domizi, E.A.; A.L. Estévez; J.A. Schnack \& G.R. Spinelli. 1978. Ecología y estrategia de una población de una población de Belostoma oxyurum (Dufour) (Hemiptera, Belostomatidae). Ecosur 5(10): 157-168.

Estévez, A.L., E. Balseiro, J. A. Schnack \& G.R. Spinelli. 1987. Ciclo anual, aspecto de la ecología reproductiva y disposición espacial de una población de Lipostemmata humeralis Berg (Hemiptera, Lygaeidae). Limnobios 2: 661-666.

Eyre, M.D. \& G.N. Foster. 1989. A comparation of aquatic Heteroptera and Coleoptera communities as a basis for environmental and conservation assessment in static watersites. J. Appl. Entomol. 108: 355-362.

Fernández, L.A. 1983. Helochares (Sindolus) talarum sp. nov., y redescripción de Helochares (Helochares) pallipes (Brullé), con descripción de los estados preimaginales (Coleoptera: Hydrophilidae). Limnobios 2: 439-449.

Fernández, L.A. 1990. Aspectos sobre la ecología poblacional de Helochares talarum Fernández. Rev. Soc. Entomol. Argent. 48(1-4): 161-165.

González, S.C. \& L.F. Valladares. 1996. The community of Odonata and aquatic Heteroptera (Gerromorpha and Nepomorpha) in a rehabilitated wetland: the Laguna de la Nava (Palencia, Spain). Arch. Hydrobiol. 136 (1): 89-104.

La Salle, J. \& I.D. Gauld. 1991. Parasitic Hymenoptera and the Biodiversity Crisis. Redia 76(3): 315-374.

López Ruf, M.L., A.O. Bachmann \& P.J. Pérez Goodwyn, 2000. Descripción de las larvas de Curicta bonaerensis (Heteroptera: Nepidae). Rev. Soc. Entomol. Argent. 59(1-4): 135-140.

López Ruf, M.L. \& A.I. Kehr. 1995. Estimación y análisis de la frecuencia de ninfas por estadio, en una población de Pelocoris (P.) binotulatus nigriculus Berg (Hemiptera: Limnocoridae). Rev. Bras. Biol. 54(1): 71-75.

López Ruf, M.L. \& P.J. Pérez Goodwyn. 2001. Description of the eggs of Curicta bonaerensis (Berg) (Heteroptera: Nepidae). Rev. Soc. Entomol. Argent. 60(1-4): 69-72.

Merritt, R.W. \& K.W. Cummins. 1996. An introduction to the aquatic insects of North America. Kendall/Hunt, Iowa, USA, $862 \mathrm{p}$. 
Millán, A., J.L. Moreno \& J. Velasco. 2001. Estudio faunístico y ecológico de los coleópteros y heterópteros acuáticos de las lagunas de Albacete. Rev. Estudios Albacetences 1(1): 43-94.

Millán, A., J. Velasco, M., L. Suárez, M.R. Vidal Abarca \& L. Ramírez-Díaz. 1996. Distribución espacial de los Adephaga acuáticos (Coleoptera) en la cuenca del río Segura (SE de la Península Ibérica). Limnetica 12(2): 13-29.

Ribera, I. \& G.N. Foster. 1993. Uso de los coleópteros acuáticos como indicadores biológicos (Coleoptera). Elytron 6(1992): 61-75

Ringuelet, R.A. 1955. Panorama zoogeográfico de la provincia de Buenos Aires. Notas Museo La Plata 18 (156): 1-15.

Samways, M.J. 1994. Insect conservation biology. Chapman \& Hall, London.

Sanchez-Fernández, D., P. Avellán, J. Velasco \& A. Millán. 2004. Areas prioritarias de conservación en la cuenca del río Segura utilizando los coleópteros acuáticos como indicadores. Limnetica 23(3-4): 209-228.

Schnack, J.A., E.A. Domizi, A.L. Estévez \& G.R. Spinelli. 1980. Determinantes ecológicos de la competencia sexual en Belostomatinae. Consideraciones sobre una población de Belostoma oxyurum (Dufour) (Hemiptera, Belostomatidae). Ecosur 7 (13): 1-13.

Schnack, J.A., E.A. Domizi, A.L. Estévez \& G.R. Spinelli. 1989. Ecología del comportamiento reproductivo de Belostomatinae. I. Sistemas de apareamiento en poblaciones del área platense de Belostoma oxyurum, B. elegans y B. micantulum (Hemiptera, Belostomatidae). Rev. Soc. Entomol. Argent. 45(14): 85-94.

Schnack, J.A., G.R. Spinelli, A.L. Estévez \& E.A. Domizi. 1986. Aspectos de la ecología reproductiva de poblaciones bonaerenses de Belostoma elegans (Mayr) y B. micantulum (Stål) (Hemiptera, Belostomatidae). Rev. Asoc. Cienc. Nat. Litor. St. Tome 17(1): 31-37.

Shanonn, C.E. \& W. Weaver. 1963. The mathematical theory of comunication. University of Illinois, Urbana, Illinois , USA. 117 p.

Sneath, P.H. \& R.R. Sokal. 1973. Numerical Taxonomy. Freeman, San Francisco, California, USA. 573 p.

Velasco, J., A. Millán \& L. Ramírez-Díaz. 1993. Colonización y sucesión de nuevos medios acuáticos I. Composición y estructura de las comunidades de insectos. Limnetica 9: 73-85.

von Ellenrieder, N. \& L.A. Fernández. 2000. Aquatic coleoptera in the subtropical-pampasic ecotone (Argentina, Buenos Aires): species composition and temporal changes. Coleopt. Bull. 54(1): 23-35.

von Ellenrieder, N. \& P. Pérez Goodwyn. 2000. Species composition and temporal variation of aquatic Heteroptera (Insecta) in the Subtropical-Pampasic ecotone in Argentina. Rev. Bras. Entomol. 44(1-2): 43-50.

\section{APPENDIX}

Species recorded

\section{COLEOPTERA}

\section{Hydrophilidae}

Berosus adustus Knisch

Derallus argentinensis Bruch

Derallus paranensis Oliva

Enochrus gentilis (Knisch)

Enochrus scutellaris (Steinheil)

Enochrus tremolerasi (Knisch)

Enochrus variegatus (Steinheil)

Enochrus vulgaris (Steinheil)

Helochares pallipes (Brullé)

Helochares talarum Fernández

Paracymus rufocinctus Bruch

Tropisternus burmeisteri Fernández y Bachmann

Tropisternus ignoratus Knisch

Tropisternus lateralis limbatus (Brullé)
Tropisternus ovalis Laporte

Tropisternus scutellaris Laporte

Tropisternus setiger (Germar)

\section{Dytiscidae}

Anodocheilus silvestrii Régimbart

Brachyvatus acuminatus (Steinheil)

Desmopachria concolor Sharp

Desmopachria sp.

Hydrovatus turbinatus Zimmermann

Laccophilus sp. 1

Laccophilus sp. 2

Laccornellus lugubris (Aubé)

Lancetes marginatus (Steinheil)

Liodessus sp. 1

Liodessus sp. 2

Pachydrus globosus (Aubé) 
Rhantus orbignyi Balke

Rhantus signatus (Fabricius)

\section{Noteridae}

Hydrocanthus debilis Sharp Hydrocanthus laevigatus (Brullé)

Hydrocanthus sharpi Zimmermann

Mesonoterus sp.

Pronoterus punctipennis Sharp

Suphis sp.

Suphisellus nigrinus (Aubé)?

Suphisellus bruchi (Zimmermann)

Suphisellus sp.

Suphisellus obesus (Regimbart)

\section{Hydrochidae}

Hydrochus orchymonti Oliva

Hydrochus richteri Bruch

\section{Dryopidae}

Dryops sp.

Onopelmus sp.

\section{Heteroceridae}

Heterocerus similis Grouvelle

\section{Limnichidae}

Eulimnichus sp.

\section{Scirtidae}

Gen. A sp. 1

\section{HETEROPTERA}

\section{Belostomatidae}

Belostoma elegans (Mayr)

Belostoma oxyurum Dufour
Notonectidae

Buenoa fuscipennis (Berg)

Notonecta sellata Fieber

\section{Corixidae}

Sigara chrostoswkii Jaczewski

Sigara platensis Bachmann

Sigara schadei (Hungerford)

Sigara sp.

Tenagobia fuscata (Stål)

\section{Mesoveliidae}

Mesovelia bila Jaczewski

\section{Veliidae}

Microvelia mimula White

\section{Gerridae}

Halobatopsis platensis (Berg)

Rheumatobates bonariensis (Berg)

\section{Pleidae}

Neoplea absona (Drake \& Chapmann)

Neoplea maculosa (Berg)

\section{Nepidae}

Rheumatobates bonariensis (Berg)

Curicta bonaerensis (Berg)

\section{Hydrometridae}

Hydrometra argentina Berg

\section{Hebridae}

Lipogomphus lacuniferus Berg

\section{Rhyparochomidae}

Lipostemmata humeralis Berg 